\title{
Comparing Modern and Classical Perspectives on Spider Silks and Webs
}

\author{
Gabriele Greco* \\ Laboratory of Bio-inspired, Bionic, \\ Nano, Meta Materials \& Mechanics, \\ Department of Civil, Environmental \\ and Mechanical Engineering, \\ University of Trento
}

\author{
Virginia Mastellari* \\ Seminar für Griechische \\ und Lateinische Philologie, \\ Albert-Ludwigs-Universität \\ Frieburg Heidelberger Akademie \\ der Wissenschaften
}

\section{Chris Holland}

Department of Materials Science and Engineering, University of Sheffield

\author{
Nicola M. Pugno \\ Laboratory of Bio-inspired, Bionic, \\ Nano, Meta Materials \& Mechanics, \\ Department of Civil, Environmental \\ and Mechanical Engineering, \\ University of Trento \\ School of Engineering and Material \\ Science, Queen Mary University \\ of London
}

We would like to acknowledge Piergiorgio di Pompeo and Luigi Lenzini (members of Aracnofilia - Italian Association of Arachnology) for the pictures. We would like to acknowledge Carme Buffa for the picture in figure 2. N.M.P. is supported by the European Commission under the FET Proactive ("Neurofibers") grant No. 732344 as well as by the Italian Ministry of Education, University and Research (MIUR) under the "Departments of Excellence" grant L. 232/2016, the ARS01-01384-PROSCAN and the PRIN-20177TTP3S grants. G.G. is supported by PRIN-20177TTP3S grant.

* Gabriele Greco and Virginia Mastellari contributed equally to the work. 
Spiders have always fascinated bumankind as whilst they are often reviled, their product, the web and its silk, are commonly viewed in awe. As such, silks' material properties and the fear and fascination surrounding the animals that spin it are seen to play an important role in the development of many cultures and societies. More recently this is even more so with the formalization of this inspiration in scientific and technical communities through biomimetics. The aim of this work is to reflect on the beginnings of our relationship with silk and discuss concepts associated with spider silks and webs in ancient Greek and Roman times whilst comparing this with our current understanding of the field. In this way, ancient texts, namely Greek and Latin ones, are found to intersect with modern advanced disciplines, ranging from architecture to medicine to physics. This allows us not only to understand how natural observation has evolved from antiquity to today, but also how such a bighly interdisciplinary research network has been spun by some shared conceptual threads.

\section{Introduction}

Humankind has been forever captivated by the marvels of nature, exemplified formally through the formation of research fields such as biomimetics (Vincent et al. 2006). Even though this term was coined only in the latter half of the twentieth century, the process of trying to extrapolate information from nature in order to address human challenges has been present in the societies of every epoque (Pugno, 2019). Naturally driven by our challenges and across the ages, the process of observation, imitation and application has defined part of our cultural and technological heritage, creating both a conceptual space and a framework for development (Holland et al. 2019). In this context, spider silks and spiders' spinning behaviors are superb examples, representing permeability throughout our culture and in several areas of technology and society (Morgan 2016, pp. 133-41).

Spider silks are made of structural proteins that are spun from liquid feedstocks into solid fibers used outside the body. Spiders can produce several different types of silks (up to seven), each one evolved through millennia of natural selection to serve a specific biological role, from eating to mating to flying (Brunetta and Craig 2012, pp. 2-15; Scott et al. 2018; Morley and Robert 2018; Greco et al. 2019; Pugno 2018). In order to perform these functions, spider silks have been under strong selection for outstanding physical properties (Eisoldt et al. 2011). Nowadays, the spider silk community has grown globally due to increasing interest in finding technological applications of these materials or overcome current limitations in materials design (Vepari and Kaplan 2007; Holland et al. 2019). Yet despite the exciting and clear focus for the future of silk, what of its past? We propose that by looking back on how our fascination with spiders and silk has developed 
we may not only appreciate more where we are going, but also the most expedient way of getting there.

Previous works have sought to provide a review of spiders and their silk in history and literature, however none through the lens of our current understanding of the animal and the material. One example is the German book by B. Rieken, Arachne and ibre Schwestern. Eine Motivgeschichte der Spinne von den 'Naturvölkermärken' bis zu den 'Urban Legends' (Münster 2003). Although the author provides the reader with a satisfactory selection of passages (the ones from ancient Greece and Rome are found at pp. 122-26), his aim was to write a "Kulturgeschichte der Spinne" ("spider's cultural history," as he points out, p. 7), and as such he does not focus on the natural nor scientific reliability when presenting ancient material. More focused on zoological knowledge in antiquity, another (still) fundamental work is the monograph published by I. Beavis, Insects and Other Invertebrates in Classical Antiquity (Exeter 1988). The author offers a very detailed account of ancient natural observations and knowledge, devoting chapter II.7 to spiders in ancient Greece and Rome (focusing on identification; natural observation; popular attitudes; etc.), the reader however still misses a broader point of view surrounding the evolution of knowledge about spiders and the human uses of spider silk. The aim of the present paper is to fill this gap by providing the reader with a more complete picture.

This work deals with the knowledge of spider silk and web-building in ancient Greece and Rome and compares it with the same underpinning concepts in modern science. Our purpose is not to discuss any and all ancient mentions of spiders; rather, we selected a number or representative passages which suited our diachronic and interdisciplinary approach. In order to give a as clear as possible picture, this paper is divided into four parts. The first deals with natural observations of spiders using their silks and web. The second relates to the material itself and its possible uses. The third concentrates on their spinning and web construction and how they were/are described and taken as a model. The final part is related to the cultural influence that spiders and their weaving had/have in human social culture.

\section{Natural Observation}

We define natural observation as the act of observing a specific phenomenon in nature and accordingly describing it. In the case of spiders, that phenomenon could be a particular spinning behavior, building a web, or notes on their biology.

The first question we should ask is: which species did the ancients know? Of the genus of arthropods, only the two orders of spiders ( $\alpha \rho \alpha \chi \chi \nu \eta / A$ raneae) and scorpions (Scorpiones) were commonly known in Antiquity. The third order, that of non-venomous barrel spiders (Solifugae/Solpugida), a scourge in Arabia and tropical Africa, was apparently found only in Greece ( $\varphi \alpha \lambda \alpha ́ \gamma \gamma \iota 0 \nu / P h a l a ́ n g i a)$ 
and Spain (Salpugae; [Plin. NH 29.92]) (Hünemörder 2001). The difference of usage between $\alpha \rho \alpha ́ \chi \nu \eta$ and $\varphi \alpha \lambda \alpha ́ \gamma \gamma \iota \mathrm{v}$ can be drawn from extant texts,

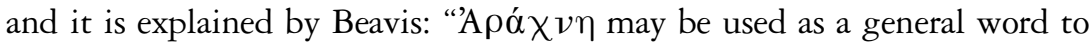
cover both classes of spiders, but in its more precise sense it comprehends those species which are known as being harmless to man, most particularly those which spins continuous webs. [...] $\Phi \alpha \lambda \alpha$ q $\gamma \gamma \iota \mathrm{v}$, on the other hand, is applied to the much-feared venomous spiders; plus those reputed to be venomous, since popular fear of poisonous creatures expanded this class of arachnids somewhat beyond its legitimate range" (Beavis 1988, p. 34; for the identification of the Phalangia varieties see pp. 46-54). The Romans on the other hand, had only one word, araneus, used for spiders in general, however for venomous species they transliterated the Greek name into phalangium.

Ancient observation and interest surrounding spiders can be traced back to one of the first literary works, Homer's Odyssey, where spider webs are mentioned twice. The first mention entails a metaphor which implies that spiders weave in abandoned places, referring to Odysseus' marital bed, which has been left empty for twenty years due to his travels away from home whilst fighting the Trojan war: Od. 16.34-35 "[...] and the couch of Odysseus, for want of sleepers, perhaps lies full of foul spider webs" (trans. Murray 1995, p. 121). The second mention involves a more elaborate image, relating to Greek mythology and the act of adultery between Ares, god of war, and Aphrodite, goddess of love. In this episode they make love illicitly, hidden in the house of Hephaistos, husband of Aphrodite. When Hephaistos finds out what happened, furious at their deceit, he arranges a trap in case they do it again. The trap is inspired by a spider web for its fineness and difficulty to be seen: "and many (bonds), too, were hung from above, from the roof beams, fine as spiders' webs, so that no one even of the blessed gods could see them, so cunningly they were fashioned" [Od. 8.272-81, esp. 279-81] (trans. Murray 1995, p. 293).

In both passages from Odyssey the spider's web plays a role in determining the sexual fidelity of a wife. ${ }^{1}$ A very close image to Odyssey 8.279-81 is also found in the tragedian Aeschylus, which is again related to, and this time architected by, a wife. Here the tragedian describes the king Agamemnon, about to die, wrapped in a spider web designed by his wife Clytemnestra: "Thou hast been brought to lie in this woven spider-web, breathing out thy life by an impious death" $[A g$. 1492-93, repeated also at 11. 1516-17] (trans. Fraenkel 1950, p. 183). Again, the spider's web is used as a sinister image, denoting cunning rather than skill and used by a weaker figure to capture a stronger one.

From a biological perspective the concept of trap is deeply relevant to a spider's life. In order to get the energy to live, they have to feed themselves

1. For a metaphorical, gender-based reading of the two Homeric passages see Holmberg 2003. 
and to feed, they hunt. In many species of spiders, the use of webs is an incredibly efficient tool to trap prey. Among the variety of traps and hunting skills displayed by spiders, two of them deserve a special mention: the evolutionarily ancient trapdoor (typically belonging to the Mygalomorphae suborder) and perhaps the most modern tangleweb of the black widow (Theridiidae family). Trapdoor spiders dig a tunnel in the soil at the end of which they build a door with silk threads elongating from it (Main 1957; see figure 1, a).

Their purpose is to extend the spiders' territory insofar that, when a prey touches one of the threads, the spider is able to pounce and immediately drag it into the very end of the tunnel, where it can be consumed. On the other hand, the trap displayed by Theridiidae spiders is very sophisticated and it can be easily associated with the one in Hephaistos's mythological episode. These spiders spin vertical threads from their cobwebs (Hódar and SanchèzPinero 2002; see figure 1, d). The threads are attached to the substrate below with unstable attachment discs that when touched, detach and lift the prey up, suspending it helplessly until eaten (Nyffeler and Vetter 2018; Greco and Pugno 2021). Another trap that is accurately described in ancient literature is the one observed by Pliny the Elder [Natural History, NH 11.28, 82] that says:

How its bosom bellies to the breezes so as not to reject things that come to it! You might think the threads had been left by a weavy weaver stretching in front at the top; but they are difficult to see, and, like the cords in hunting-nests, when the quarry comes against them throw it

a)

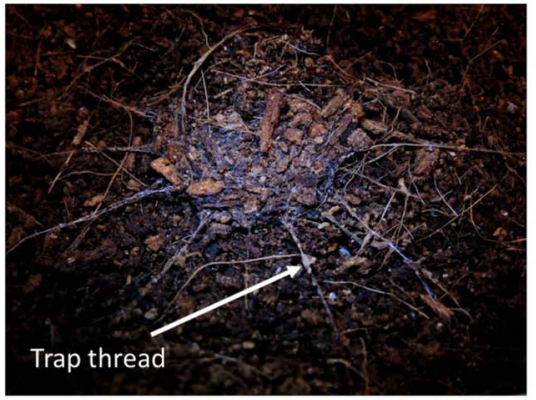

b)

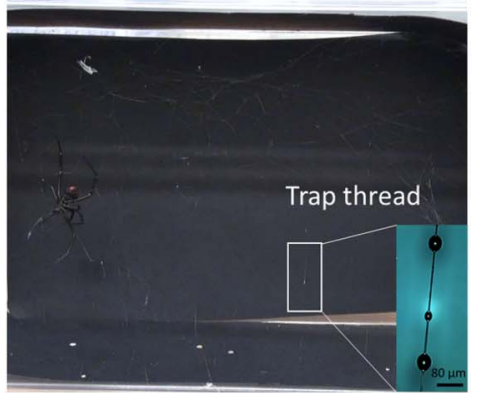

Figure 1. a) The entrance of the den of a trapdoor spider with the silk threads that line outside "the door." Courtesy of Aracnofilia (Italian Association of Arachnology; photo by Piergiorgio Di Pompeo). b) Structure of the cobweb produced by Latrodectus tredecimguttatus. The vertical threads are traps that are used to lift the prey, usually ants, and thus make it impossible to escape by gripping on the surface below. (Photo by Gabriele Greco.) 
into the bosom of the net. With what architectural skill is the vaulting of the actual cave designed! And how much more hairy it is made, to give protection against the cold! (trans. Rackham 1940, p. 483).

This quotation is interesting for two reasons. The first one relates to the accuracy of describing a trap with vertical threads. This could be related to the webs of Linyphidae spiders that normally build a 3D structure composed of a canopy surrounded by vertical threads which serve to catch flying prey before throwing it into the canopy (Foelix 2011, pp. 155-57). Interestingly, the description of Pliny seems to be very precise and similar to the one of recent biology manuals. In Foelix one reads:

The very delicate webs of the linyphiids are also horizontal, but convex, sheets with similar vertical threads that serve as tripping lines for insects [...] In most cases an insect becomes trapped between the vertical "knock-down" threads. The spider, hanging beneath its sheet, quickly rushes by and shakes the web so that the victim will fall down. The bite is applied through the fine meshwork of the horizontal sheet, and the victim is pulled down. (2011, p. 155)

The second aspect is even more peculiar. Pliny seems to refer to the fact that silk is a good thermal insulator. This intuition has been confirmed by modern achievements on the properties of spider silk and it is the reason why spiders are able to overcome the cold winter by insulating themselves in a silk cocoon (Cunniff et al. 1994). Recent work has also identified silks to be very efficient thermal conductors, although this appears to still be a controversial area in the literature (Huang et al. 2012; Xing et al. 2013; Fuente et al. 2014).

However, it is not just the properties of silk in the web that has captured the attention of the ancients, but their architecture also, with the best known being the orb web (figure 2).

Excluding literary metaphors or mythological accounts it was Aristotle who first described in the History of Animals spider spinning behavior and web construction [HA 623a 9-17].

It weaves by first stretching thread to the extremities in every direction, then it lays down the radii from the middle (it takes the middle with fair accuracy) and on these lays down the woof so to speak, and then weaves them together. Now the bed and storage she arranges elsewhere, but she does her hunting at the centre where she keeps watch. Then when something has fallen in and the centre has been moved, first she binds it round and enwraps it with webs until she has made it helpless, then she lifts it up and carries it away ... (trans. Balme 1991, pp. 329-31. A commentary to the passage is in Beavis 1988, pp. 36-7, 41) 


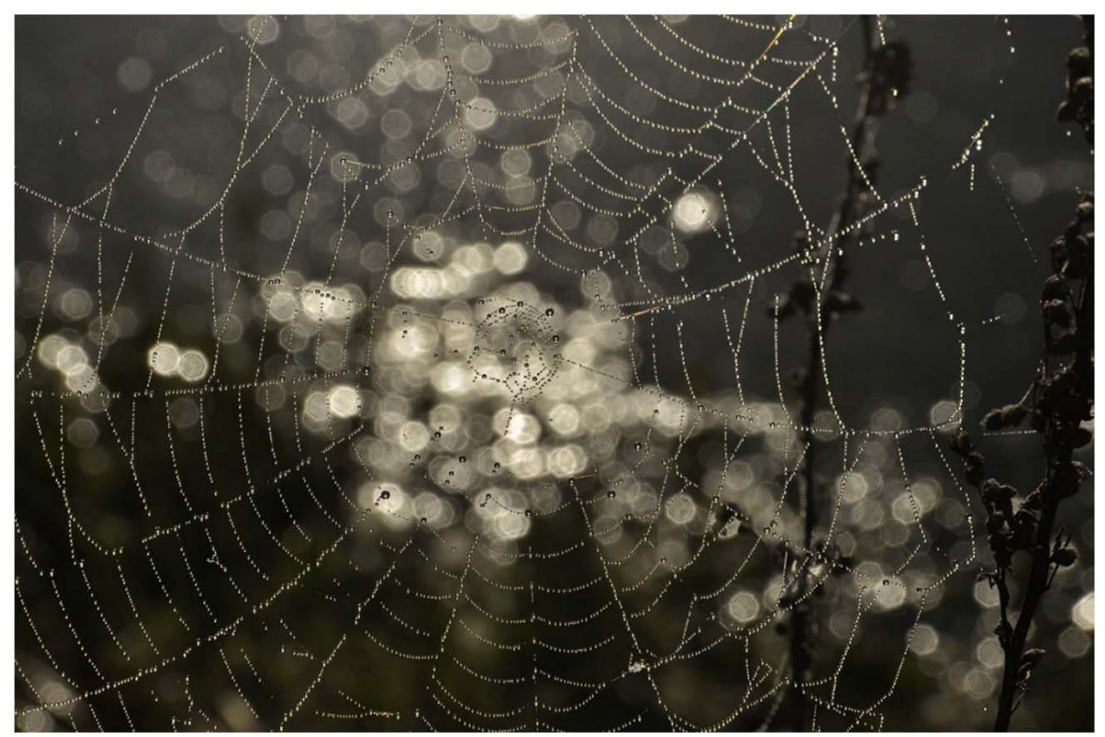

Figure 2. Orb web produced by a Larinioides sp. Also after heavy rains, orb webs remain efficient and capable of stopping flying prey, sometimes with even an improvement (Greco et al. 2019). Courtesy of Carmen Buffa.

The first aspect to be noted is the accurate description of the hunting, which resembles modern scientific literature (Foelix 2011, pp. 157-80). In particular, many orb-weavers monitor thread vibrations, which could be caused by potential prey or a mate, at the center of the webs (Masters and Markl 1981). Nowadays, we know that the propagation of such vibrations can be tuned, like a musical instrument, by the spiders in order to optimize signal transmission in the web (Mortimer et al. 2014; Mortimer et al. 2016). Moreover, this passage is very interesting for two reasons. The first is the comparison with human weaving, since Aristotle employs the word "woof" which is normally used in ancient Greek to describe human manufacture. We will show in paragraph 3 the relevance of comparing human and animal spinning and how spiders' weft is seen as an example to imitate. Secondly, the parallel to geometry, entailed by the sentence "it takes the middle with fair accuracy."

This last comparison is also found in another text, namely The Characteristics of Animals by Aelian [NA 6.57], who remarks that the spider has no need of Euclid (the most famous ancient scholar of geometry):

It seems after all that spiders are not only dexterous weavers after the manner of Athena [... but but they are by nature clever at geometry.

Thus, they keep to the centre and fix with the outmost precision the 
circle with its boundary based upon it, and have no need of Euclid, for they sit at the very middle and lie in wait for their prey (trans. Schonfield 1959, pp. 77-9).

This observation, apparently without a context, can be inserted in a broader discourse: the ancients applied also to the spider the dichotomy between $\tau \dot{\chi} \chi \nu \eta$ (techne) and $\varphi v$ oıs (physis), 'art' and 'nature', asking if the spinning ability of spiders was learned (techne) or innate (physis). Both Aristotle (in the 4th century BC) and Aelian (in the 2nd century AD) in the two passages above asked themselves this very question and concluded that it was actually an innate characteristic. The hallmarks of this innate sense are that it comes untaught and it is shown by all members of a given species in the same manner: "the instincts of animals are untaught," says Hippocrates [Nutriment 39.1]; Galen adds: "it seems to me that other animals acquire their skills by instinct $[\ldots]$ and spiders spinning and weaving. I judge from the fact that they are untaught" [On the Usefulness of the Parts 1.3] (trans. May 1968, p. 70). For a detailed account see also Dickerman 1911, who shows to what extent the ancients admired works of animals, among which spiders were praised for their intelligence.

Nowadays we know that spiders spin webs using genetically encoded information which manifest as a sublime set of built-in rules that can be followed from hatching (Reed et al. 1970; Witt et al. 1972; Krink and Vollrath 1997). However, like all of nature, there is flexibility in these rules and spiders are actually able to modify their webs to adapt to their environment and improve their efficiency when necessary (Foelix 2011, pp. 180-82; Herberstein 2012, pp. 57-85; Boutry and Blamires 2013).

\section{The Material: Spider Silk}

The first thing that was noticed in antiquity (and that today is still source of fascination) is the fact that spider silk is strong and spider webs robust. When compared to our own materials, many spider silks are stronger than steel and more deformable, allowing spiders to capture and lift objects or prey, even bigger than themselves (see Figure 3, a) (Foelix 2011, pp. 180-82; Herberstein 2012, pp. 57-85; Boutry and Blamires 2013; Greco and Pugno 2020; Vollrath and Porter 2006).

This unique combination of strength and deformability leads to the property of most interest for today's researcher, toughness, the ability to absorb energy before breaking, of which spider silk is unmatched in nature (Agnarsson et al. 2010). In this sense, an accurate description of the spider web is found in Pliny's Natural History [NH 11.28, 83-4]:

Then its strength - when is it broken by the winds? What quantity of dust weighs it down? When the spider is practicing its art and 
learning to weave, the breadth of the web often reaches between two trees and the length of the thread stretches down from the top of the tree and there is a quick return right up the thread from the ground, and the spider goes up and brings down the threads simultaneously. But when a catch falls into the web, how watchfully and alertly it runs to it! Although it may be clinging to the edge of the net, it always runs to the middle, because in that way it entangles the prey by shaking the whole (trans. Rackham 1940, p. 483).

Although our awareness has deep roots, only recently has one of the reasons spider orb webs are so efficient in bearing wind loads been discovered. Namely, spiders produce special anchorages on the surfaces made of a specific silk used only for this purpose (Cranford et al. 2012; Pugno et al. 2013; Greco et al. 2020b).

Mechanical properties apart, being a natural and a protein-based material, spider silk has interesting biological properties. It is indeed not perceived as a threat by human body cells, an observation scientifically proven this century when the first studies on the cytocompatibility of spider silk were performed (Allmeling et al. 2006). Moreover, it seems that bacteria struggle to proliferate and grow on spider silk's surface due to an absence of available nitrogen (Zhang et al. 2019). These properties, thus, have become extremely interesting in terms of possible biomedical applications. However, the possibility to use

a)

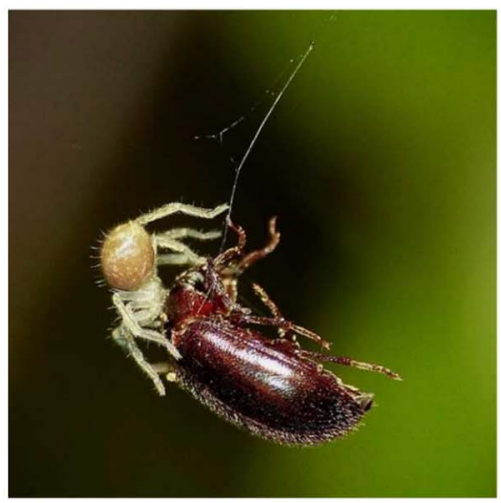

b)

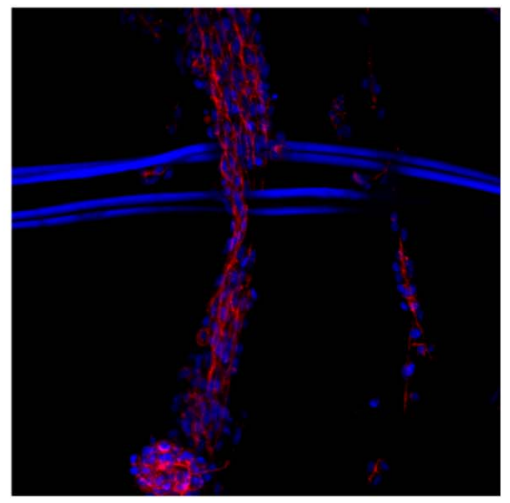

Figure 3. a) Olios argelasius spider that uses a silk thread to lift a prey. Courtesy of Aracnofilia (Italian Association of Arachnology, picture by Luigi Lenzini).

b) The silk of Linothele megatheloides spider seems to be better accepted by cells, which adhere and proliferate on it more than in more common silkworm silk fibers. Adapted from Yang et al. 2020. 
spider silk as a basic material for medical purposes is far from recent (Holland et al. 2019). In particular, the medical use of spider silk is documented by various ancient sources. Dioscorides Pedanius, an ancient Greek doctor, botanic and pharmacist who lived in Rome during Nero's age (1st century AD), stated that spider silk can be used to heal the third and the fourth fever. On the other hand, in his work On Medical Material he said that, if boiled with other ingredients, spider silk is useful against earache [MM 2.63]:

Spider, the animal, which some call 'holkos' or 'lykos', kneaded on a limen pad, plastered onto a linen cloth, and applied to the forehead or the temples, cures fits of tertian fever. When plastered on, its web staunches the blood and maintains the surfaces of sores free of inflammations. There is also another type of spider that spins its web white and dense. It is reported that this web cures fits of quartan fever when packed in a pouch and hung from the arm. And it helps for earaches when boiled with unguent of roses and the liquid is instilled into the ears. (trans. Beck 2017, p. 108)

Moreover, Galen documented the use of the silk as uninflammatory to protect shallow wounds [On Simple Drugs, vol. 12, p. 343, 1 Kühn]. However, the richest account of the uses of spider silk for medical purposes was given by Pliny in Natural History, a fundamental work for ancient Romans who started to get in touch with foreign remedies. Pliny indeed did little, if any, independent research, but collected receipts, botanical and animal, from any source available to him at the time. Spiders and their silk are found as treatments for a wide variety of diseases and health conditions: for the breasts after delivery [NH 30.131]; fractured skull and for bleeding after razor wound [NH 29.114]; eye fluxes [NH 29.131-32]; bruised joints [NH 30.78]; to be put on temples to cure fever [NH 30.104] or nose bleeding [NH 30.112]; for teeth problems [NH 30.27] and also for earache [NH 30.26] (Jones 1963). Accounts of use by later authors are given in Beavis (1988, pp. 43-4).

Importantly the potential to use spider silks in medicine has never vanished from our culture. What has changed though is the field of medicine itself and the applications for silk (Holland et al. 2019). One example of the chronological persistence of the relationship between spider silk and medicine is given by the study of M. Bon (1710), the first published scientific paper dealing with spider silk in medicine. In that work, together with the description of some methodologies to collect the silk, Bon described how spider silk could be used not only for manufacturing and fabrics, but also as an example to take inspiration from for developing medical technologies.

Nowadays, the focus of spider silk in medical applications has shifted from the past, where mainly fibers and extracts were exploited (Tahir et al. 2017; 
Holland et al. 2019). Whilst the range of applications is not yet as broad or as deep as those exploited by the ubiquitous silk from the mulberry silkworm Bombyx mori (see figure 3, b), new biomedical applications of spider silks have been discovered and largely pivot around the paradigm-shifting discovery of recent times that silks can be unspun. For spider silk, the most common uses to date requires transforming fibers into hydrogels, nanoparticles, films, or foams which are used primarily for tissue engineering or drug delivery (Huemmerich et al. 2006; Humenik et al. 2011; Schacht et al. 2015; Jastrzebska et al. 2018; Gustafsson et al. 2018; Dellaquila et al. 2019; Yang et al. 2020). However, progress in this area requires innovation in up-scaling, as these applications require large amounts of spider silk (Rising and Johansson 2015; Greco et al. 2020a), and this in particular, much like the calls of M. Bon 300 years ago (Bon 1710), represents one of the main challenges for the field (Koeppel and Holland 2017; Edlund et al. 2018).

Hence, we have discussed how the material itself is therefore interesting and remarkable in properties, but even more notable is how spiders build webs. The skills of creating synergy and efficiency in structures is a peculiarity of spiders, the only creatures capable of a perfect balance between the quantity and the topology of the materials with the supreme efficiency of the overall structure: the web.

\section{Spider Weaving as a Model}

The significance of weaving within ancient societies, especially the Athenian one, has been investigated by several anthropologists, among which $\mathrm{J}$. Scheid and J. Svembro in their book Le metier du Zeus: Mythe du tissage et tissue dans le monde gré co-romain (Paris 2003). We shall not repeat their conclusions here, rather we shall focus on the relationships between the spinning of spiders and the weaving of men, and the imagery which the comparison originates.

In archaic Greek literature, the spider's art is mentioned in relation to the weaving of the women in Hesiod, Works and Days (pp. 776-78). In this passage, we find the spider and its weaving as something that the man should imitate for his craft, thus the spider is seen as an example to mirror.

[...] but the twelfth is much better than the eleventh. It is on that day that the high-flying spider spins its web in the fullness of the day and the canny one [i.e. the ant] gathers together its heap. (trans. Laks and Most 2006, pp. 149-51)

According to the philosopher Democritus (quoted by Plutarch, On the Cleverness of Animals 974a), the spider is, together with other animals, an excellent example of how humans can improve their crafts of weaving and mending. The concept of mending is particularly interesting, for nowadays 
we know that not all the spiders mend their webs in nature (Foelix 2011, pp. 157-80). Hence by observing this natural phenomenon not only helps us to describe the species observed, but it also makes us realize the accuracy of the natural study in these times:

"[...] animals $[\ldots]$ of which Democritus affirms that we have been the pupils in the most important matters: of the spider for weaving and mending; of the swallow for house building; of the singing birds, the swan and nightingale, for song, by imitation. (trans. Laks and Most 2016, p. 247)

The mending of spider webs is also found in Aristotle [HA 623a] and Pliny [NH 9.84]. Aristotle [HA 623a] and Aelian [NA 6.57] infer that the repairs are made at sunrise or sunset, because these are the times when most insects are likely to be caught. As anticipated, there are species of spiders that actually repair their webs by replacing missing threads, typically in their spirals, however some entirely rebuild their webs every day (Foelix 2011, pp. 157-80). From an evolutionary perspective in order to be successful, both approaches have been selected to minimize the consumption of energy required by the spider to acquire more food (i.e., the energetic costs of web production and maintenance) (Scharff et al. 2019). This poses the question of where the success in relation to the reconstruction of the web stems from. Some related intuition can already be found in a passage by Plutarch. In the same work where Democritus is cited, Plutarch indeed proposed his own accurate observation [On the Cleverness of Animals 966e-67a]:

There is more than one reason for admiring spiders' webs, the common model for both women's looms and fowlers' nets; for there is a fineness of the thread and the evenness of the weaving, which has no disconnected threads and nothing like a warp, but is wrought with the even continuity of a thin membrane and a tenacity that comes from a viscous substance inconspicuously worked in. Then too, there is the blending of the colors that gives it an airy, misty look, the better to let it go undetected; and most notable of all is the art itself, like a charioteer's or a helmsman's, with which the spinner handles her artifice. When a possible victim is entangled, she perceives it, and uses her wits, like a skilled handler of nets, to close the trap suddenly and make it tight. Since this is daily under our eyes and observation, my account is confirmed. Otherwise it would seem a mere fiction [...]. (trans. Cherniss and Helmbold 1957, p. 365)

Plutarch clearly identified that webs are composed not only of one single material, but of different types of silk. Because of this, certain orb webs 
minimize their damage after an impact with a flying object (Cranford et al. 2012). Being minimized, the damage does not affect the overall robustness of the structure and as such does not need to be repaired or rebuilt, as it still capable of stopping flying prey (Meyer et al. 2014; Asakura and Miller 2014, pp. 240-47). In fact, to achieve this the different silks have a huge mechanical synergy (Greco et al. 2019; figure 4).

Moreover, these quotations show how ancient Greek authors considered the spider and spinning as something that humankind can eventually replicate in its weaving and fishing activities. In other words, the spider is seen as a model for learning from nature. As for the fishing, the uses of spider silks as tools in fishing activities are not confined to the aforementioned quotation. A paper by A. Gell in 1988 shows that spider silks were used by populations of the Solomon Islands as a bait for fishing activities, even if there is no clear evidence on what specific role spider silk covered (Barton and

a)

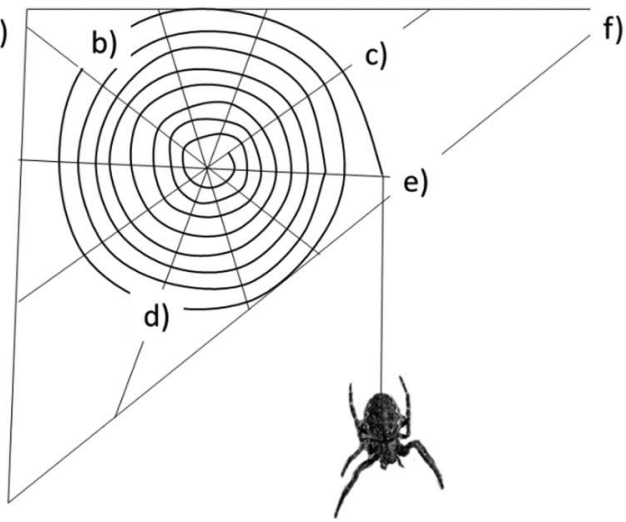

d)

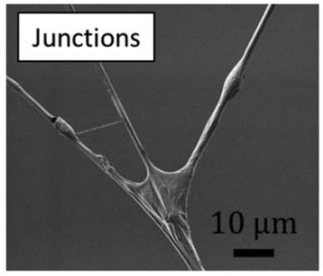

e)

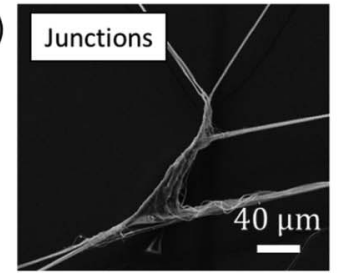

b)

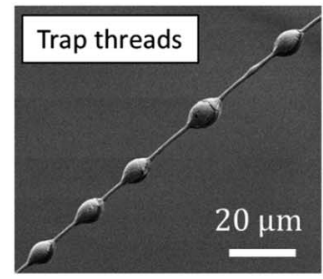

c)

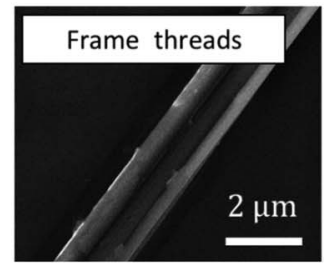

f)

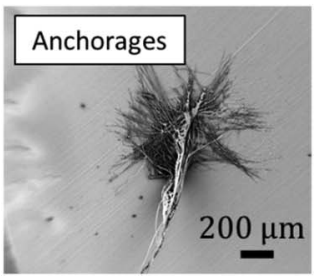

Figure 4. a) Nuctenea umbratica is an orb weaver that produces orb web made by frame threads (c), which are different with respect to the threads used to trap the prey. The web is secured to surfaces by means of anchorages that are produced with the same silk used to join threads along the edges (e). The junctions inside the spiral, on the other hand, are produced by means of a glue (d) that is the same used to produce the glue droplets in the trap threads (b). Adapted from Greco et al. (2019). 
Dietrich 2009, pp. 195-213). It is therefore clear how spider silks spinning and web building can be inspiring for human purposes. Although this influence has been crucial in developing and designing smart technologies and techniques, it plays a huge role in deeply affecting our cultural heritage (Asakura and Miller 2014, pp. 240-47; Basu 2015, pp. 233-37; Miniaci et al. 2016; Salehi et al. 2020; Guo et al. 2020; Pan et al. 2020).

\section{Cultural Influences}

Spiders, spider silks and webs have a huge effect on our feelings and behavior. This is scientifically demonstrated by the fact that arachnophobia, the fear of spiders, is recognized as a mental disorder with medical treatments being available (Bouchard et al. 2014; Granado et al. 2007; St-Jacques and Renaud 2006). This mental state has deep origins and, as we shall explore, is embedded in our cultural heritage.

The best-known (and most continuative from a chronological point of view) artistic expression that sees a spider as a main character is the myth of Arachne. Whilst being a Greek myth, the first detailed expression can be found in Latin literature: Ovid's Metamorphoses, Book 6 (for a detailed account of the narration see e.g., Johnson 2008, pp. 74-95). Arachne was a shepherd's daughter who started weaving when very young. She quickly acquired great ability in weaving that led her to boast about herself as a better weaver than Athena and refused to acknowledge that this was only because of the goddess that she had talent in the first place. This offended Athena who challenged the young girl to weave a more beautiful yarn than her own. Athena's work represented four different competitions between mortals and gods with gods punishing the mortals because they dared to put themselves at their level. Arachne's work, on the other hand, represented scenes where gods fooled and abused mortals. When Athena realized that the work of Arachne not only insulted the gods but her work was also superior, she destroyed it in a fit of rage and hit her on the temple three times. Arachne, moved by desperation, took a noose and was ready to hang herself when Athena stopped her [Ov. Met. 6.134-45]:

The wretched girl could not endure it, and put a noose about her bold neck. As she hung, Pallas lifted her in pity, and said: "Live on, indeed, wicked girl, but hang thou still; and let this same doom of punishment (that thou mayst fear for future times as well) be declared upon thy race, even to remote posterity." So saying, as she turned to go she sprinkled her with the juice of Hecate's herb; and forthwith her hair, touched by the poison, fell off, and with it both nose and ears; and the head shrank up; her whole body also was small; the slender fingers clung to her side as legs; the rest was belly. Still from this she ever spins 
a thread; and now, as a spider, she exercises her old-time weaver-art.

(trans. Miller 1977, pp. 297-99)

If, as we have seen in the previous paragraphs, in other literary works humans have learned the art of weaving by observing spiders, Arachne's myth inverts this correlation: from a human skilled at weaving comes the most expert animal in this craft, the spider. However picturesque and fascinating, Arachne's myth is not the history of an award but the opposite, that of a punishment-being transformed into a spider. As Rieken (1995) stresses in an article about spiders as symbols in popular tradition and literature, Arachne's myth deals with the question of ability and power, because the Lydian weaver not only wants to be better than any other person, but also better than the gods, which sparks the anger of Athena. As Ovid remarks, "non illa loco neque origine gentis clara, sed arte fuit" ("The one was not famous by origin or descent, but by art"): Arachne comes from a humble background and has clear aspirations, but she exaggerates in her will to outdo the gods. On the other hand, Athena's behavior is also characterized by the interdependence between feelings of inferiority and striving for power. One may object that it is part of the logic of the divine to punish arrogance, but in this myth it gets more personal: Athena is outraged by a mortal and instead of showing superiority, appropriate to a god's behavior, she shows human weaknesses by becoming angry and makes harmless that what threatens her.

From a cultural perspective the prevalence and popularity of this myth has most likely influenced our attitude toward the spider as it is likely to be closely linked to fear of threats related to the power assigned to it. One can easily say that Arachne's myth started a chain of imagery and implications which depict spiders as negative and sources of fear in several different cultures, but also began the fascination with their artistry. As Kulessa (1991) notices in the preface of her book about spiders, there is no book outside strictly zoological literature "that does not deal with the feelings of fear and disgust that [...] the eight-legged animal triggers in humans in the preface or introduction" ("[Buch] das sich im Vorwort oder der Einleitung [...] nicht mit den Angstund Ekelgefühlen beschäftigt, die das achtbeinige [...] Tier bei den Menschen auslöst”). Nevertheless, as Iles Johnston (2009, pp. 6-7) shows, the affordance related to a subject, the spider for instance, allows the possibility that both positive and negative meanings and feelings can be evoked within a single cultural production. For example, the act of weaving webs discussed above is sometimes understood to indicate industriousness (as in Hesiod Op. 777, Aristotle $H A$ 622b 23, Aelianus NA 1.21; all quoted above), but at the same time it could signify neglect, carelessness (a place abandoned by humans, as Odysseus' marital bed covered in webs after his long absence; noted above. More examples can be found in Beavis 1988, p. 40). The web is sometimes 
seen as a fine work, produced by intelligent creatures (as in Aristotle HA 623a; quoted above) and sometimes just a symmetrical product of instinct rather than art (as in Hippocrates Nutriment 39.1 and Galen On the Usefulness of the Parts 1.3; quoted above).

Apart from the psychological implications of Arachne's myth across time, her story has forever permeated western culture and stimulated and inspired several artistic expressions. To mention a representative one, Gustave Dorè depicted Arachne's transformation in an intense painting inspired by Dante's Purgatory 12 (see figure 5, a). The painting portrays the peculiar position of an arachnid overturned from behind and the metamorphosis represented at an advanced stage since all that remains of the human is the face. The intensity of the painting is such that the Italian writer Primo Levi (1985) recognized in it the origin of his arachnophobia.

Other pictorial representations are collected and explained in the survey by Ballestra-Puech De la toile tissée a la toile peinte (2006). However, the artistic means of expression is not limited to pure painting. In architecture, the imagery of the spider web can be exploited in several ways. Victor Hugo (1837) personified Paris comparing it to a "araignée à la immense toile," referring to the perfection and symmetry of the city (Gély 1985, p. 821). Moreover, the Tour Eiffel has been described by the brothers Edmond and Jules de Goncourt as having a "architecture arachnéenne (De Goncourt and De Goncourt 1889)." In more recent times, the Italian architect Mario Botta in collaboration with the engineer Giulio Andreolli, inspired by the spider, realized the MART (Museum of Modern and Contemporary Art of Trento and Rovereto) ceiling (see figure $5, \mathrm{~b}$ ).

a)

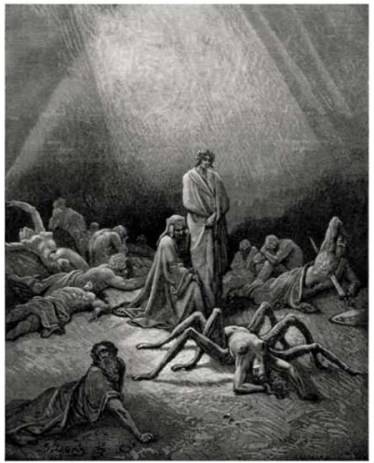

b)

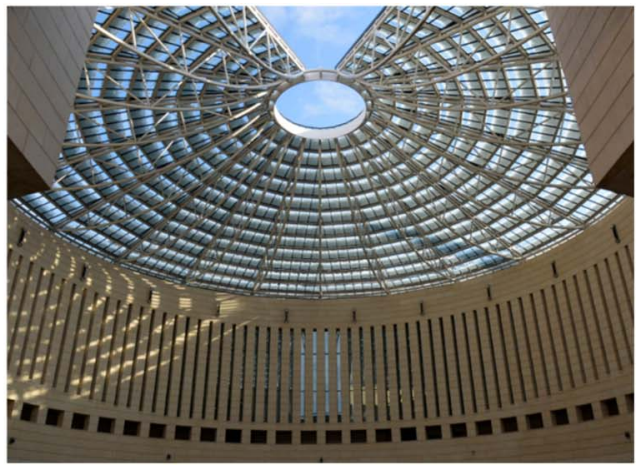

Figure 5. a) Gustave Doré “Arachné au purgatoire” (Paris, Hachette, 1868).

b) Ceiling of MART (Museum of Modern and Contemporary Art of Trento and Rovereto) (photo: www.visitrovereto.it). 
Although there is no straightforward interpretation, it seems clear that the shape of such a building resembles the structure of an orb web (see figure 2), perhaps as symbol of solidity. Another example of the influence of spider webs in architecture can be found in the pavilion designed by the University of Stuttgart, inspired by the aquatic spider Argyroneta aquatica (Knippers et al. 2016, pp. 61-3). This peculiar spider lives almost its entire life under water, where it builds the web with the shape of a bell (Mammola et al. 2016). This structure is filled with air by the spider and allows the animal to live inside it without the need to venture outside for several days (Neumann and Woermann 2013). Recently, this has been shown to be possible because of the peculiarity of this structure, which acts as a physical gill (Seymour and Hetz 2011). Finally, the remarkable work of Tomás Saraceno should be mentioned. This artist emphasizes the connecting, aerial, and floating character of the webs to conceptualize the design of floating architectures or the interconnections within the cosmos (Horn et al. 2018).

There is no space here to investigate the numerous literary expressions of spider imagery and the re-uses and re-interpretations of Arachne's myth up to the modern day, for which it shall suffice to remember the works by BallestraPuech (2006) and Reinhardt (2014; this last one limited to Arachne).

\section{Conclusion}

Dealing with spider silks and webs means dealing with a part of our own culture. In this work, we have shown a comparison of the concepts related to spider silks and webs between ancient (Greek and Roman as an example of a cultural heritage) and modern societies. We have presented some examples of natural observations performed by ancient people that resemble the modern ones, highlighting the innovativeness of ancient thought. Then we have shown to what extent spider silks were perceived as a peculiar material with huge potential uses for humankind. The act of weaving itself was seen in the past as a source of inspiration, as much as nowadays. Finally, we have shown the continuity of spider silks and webs in affecting our culture from many different points of view.

The past is tremendously different with respect to the present. Some ways of thinking and seeing things have totally changed during the evolution of our society. But we can still find common features which highlight the modernity and novelty of some ancient thinkers that established the basis of our culture. In order to proceed in developing technologies and prosper in our scientific future, we must keep strongly in mind the history of our culture and how has it evolved. We hope that this work gives the basic knowledge to start comparative and interdisciplinary studies between ancient and modern science and culture. 


\section{References}

Agnarsson, I. et al. 2010. "Bioprospecting Finds the Toughest Biological Material: Extraordinary Silk from a Giant Riverine Orb Spider." PLoS One 5(9), e11234. DOI: https://doi.org/10.1371/journal.pone.0011234, PMID: 20856804, PMCID: PMC2939878

Allmeling, C. et al. 2006. "Use of Spider Silk Fibres as an Innovative Material in a Biocompatible Artificial Nerve Conduit." J. Cell. Mol. Med. 10: 770-777. DOI: https://doi.org/10.1111/j.1582-4934.2006.tb00436.x

Asakura, T., and T. Miller. 2014. Biotechnology of Silk. Heidelberg: Springer. DOI: https://doi.org/10.1007/978-94-007-7119-2

Ballestra-Puech, S. 2006. Métamorphoses d'Arachné. L'artiste en aragnée dans la litté rature occidentale. Genève: Droz.

Balme, D. M. 1991. Aristotle. History of Animals 3. Books 7-10. Cambridge, MA: Harvard University Press.

Barton, G. and Dietrich, S. 2009. The Ingenious and Singular Apparatus: Fishing Kites of the Indo-Pacific. Illustrated with Figures of the Things Described. Heidelberg: BoD.

Basu, A. 2015. Advances in Silk Science and Technology. Boston: The Textile Institute. Beavis, I. C. 1988. Insects and other Invertebrates in Classical Antiquity. Exeter: University of Exeter Press. DOI: https://doi.org/10.5949/liverpool 19780859892841.001.0001

Beck, L. Y. 2017. Pedanius Dioscorides of Anazarbus, De Materia Medica, 3rd rev. edn. Hildesheim-Zürich-New York: Olms-Weidmann.

Bon, M. 1710. "A Discourse upon the Usefulness of the Silk of Spiders." Philosophical Transactions of the Royal Society 27: 2-16. DOI: https://doi .org/10.1098/rstl.1710.0001

Bouchard, S. et al. 2014. "Arachnophobia and Fear of Other Insects: Efficacy and Lessons Learned from Treatment Process." Pp. 91-117 in Advances in Virtual Reality and Anxiety Disorders. Edited by B. K. Wiederhold, and S. Bouchard. New York: Springer. DOI: https://doi.org/10.1007/978-1 -4899-8023-6_5

Boutry, C., and Blamires, S. J. 2013. "Plasticity in Spider Webs and Silk: An Overview of Current Evidence." Pp. 1-46 in Spiders: Morphology, Behavior and Geographic Distribution. Edited by M. Santerre. Hauppauge, New York: Nova Science Publishers, Incorporated.

Brunetta, L., and Craig, C. L. 2012. Spider Silk Evolution and 400 Million Years of Spinning, Waiting, Snagging, and Mating. Yale University Press.

Cherniss, H., and W. C. Helmbold. 1957. Plutarch's Moralia. Vol. 12. 920a-999b. Cambridge, MA/London: Harvard University Press.

Cranford, S. W. et al. 2012. "Nonlinear Material Behaviour of Spider Silk Yields Robust Webs." Nature 482: 72-76. DOI: https://doi.org/10 .1038/nature10739, PMID: 22297972 
Cunniff, P. M. et al. 1994. "Mechanical and Thermal Properties of Dragline Silk from the Spider Nephila Clavipes." Polymers for Advanced Technologies 5: 401-410. DOI: https://doi.org/10.1002/pat.1994.220050801

De Goncourt, E., and J. De Goncourt. 1889. Journal des Goncourt. Mémoires de la vie Littéraire. Mercredi, 6 Mars.

Dellaquila, A. et al. 2019. "Optimized Production of a High-Performance Hybrid Biomaterial: Biomineralized Spider Silk for Bone Tissue Engineering." Journal of Applied Polymer Science 137: 48739. DOI: https:// doi.org/10.1002/app.48739

Dickerman, S. O. 1911. "Some Stock Illustrations of Animal Intelligence in Greek Psychology." Transactions of the American Philological Association 42: 123-130. DOI: https://doi.org/10.2307/282577

Edlund, A. M. et al. 2018. "Economic Feasibility and Environmental Impact of Synthetic Spider Silk Production from Escherichia Coli." New Biotechnology 42: 12-18. DOI: https://doi.org/10.1016/j.nbt.2017.12.006, PMID: 29277712

Eisoldt, L. et al. 2011. "Decoding the Secrets of Spider Silk." Materials Today 14: 80-86. DOI: https://doi.org/10.1016/S1369-7021(11)70057-8

Foelix, R. 2011. Biology of Spiders. Oxford: Oxford University Press.

Fraenkel, E. 1950. Aeschylus, Agamemnon. Oxford: Clarendon Press. DOI: https://doi.org/10.1093/oseo/instance.00178516

Fuente, R. et al. 2014. "Revising the Exceptionally High Thermal Diffusivity of Spider Silk." Materials Letters 114: 1-3. DOI: https://doi.org/10 .1016/j.matlet.2013.09.092

Gell, A. 1988. "Technology and Magic." Anthropology Today 4: 6-9. DOI: https://doi.org/10.2307/3033230

Gély, C. (1985). Victor Hugo. OEurres completes, Poésie 1. Paris: Laffont.

Granado, L. C. et al. 2007. "Spiderless Arachnophobia Therapy: Comparison between Placebo and Treatment Groups and Six-Month Follow-Up Study." Neural Plasticity 11: 10241. DOI: https://doi.org/10.1155 /2007/10241, PMID: 17713595, PMCID: PMC1940059

Greco, G. et al. 2019. "Imaging and Mechanical Characterization of Different Junctions in Spider Orb Webs." Scientific Reports 9: 5776. DOI: https://doi .org/10.1038/s41598-019-42070-8, PMID: 30962468, PMCID: PMC6453893

Greco, G., and Nicola M. Pugno. 2020. "Mechanical Properties and Weibull Scaling Laws of Unknown Spider Silks." Molecules 25: 2938. DOI: https:// doi.org/10.3390/molecules25122938, PMID: 32604727, PMCID: PMC7355793

Greco, G., \& Pugno, N. M. 2021. "How Spiders Hunt Heavy Prey: The Tangle Web as a Pulley and Spider's Lifting Mechanics Observed and Quantified in the Laboratory." Journal of the Royal Interface, 18, 1820200907. DOI: https://doi.org/10.1017/S0952836902000699 
Greco, G. et al. 2020a. "Properties of Biomimetic Artificial Spider Silk Fibers Tuned by Post Spin Bath Incubation." Molecules 25: 3248. DOI: https:// doi.org/10.3390/molecules25143248, PMID: 32708777, PMCID: PMC7397010

Greco, G. et al. 2020b. "Strong and Tough Silk for Resilient Attachment Discs: The Mechanical Properties of Piriform Silk In The Spider Cupiennius salei (Keyserling, 1877)." Frontiers in Materials 7: 138. DOI: https://doi.org/10.3389/fmats.2020.00138

Guo, C. et al. 2020. "Engineering Silk Materials: From Natural Spinning to Artificial Processing." Applied Physics Reviews 7: 011313. DOI: https:// doi.org/10.1063/1.5091442

Gustafsson, L. et al. 2018. "Structuring of Functional Spider Silk Wires, Coatings, and Sheets by Self-Assembly on Superhydrophobic Pillar Surfaces." Advanced Materials 30: 1704325. DOI: https://doi.org/10 .1002/adma.201704325, PMID: 29205540

Herberstein, M. E. 2012. Spider Behaviour: Flexibility and Versatility. Cambridge: Cambridge University Press.

Hódar, J. A., and F. Sanchèz-Pinero. 2002. "Feeding Habits of the Black Widow Spider Latrodectus Lilianae (Araneae: Theridiidae) In an Arid Zone of South-East Spain." The Journal of Zoology 257: 101-109. DOI: https://doi.org/10.1017/S0952836902000699

Holland, C. et al. 2019. "The Biomedical Use of Silk: Past, Present, Future." Advanced Healthcare Materials 8: 1800465. DOI: https://doi.org/10 .1002/adhm.201800465, PMID: 30238637

Holmberg, I. E. 2003. "Hephaistos and Spiders' Webs." Phoenix 57(1/2): 1-17. DOI: https://doi.org/10.2307/3648485

Horn, E., T. Morton, and T. Ingold. 2018. Tomas Saraceno: The Aerocene Project. Milano: Skira Editore.

Huang, X. et al. 2012. "New Secrets of Spider Silk: Exceptionally High Thermal Conductivity and Its Abnormal Change under Stretching." Advanced Materials 24: 1482-1486. DOI: https://doi.org/10.1002 ladma.201104668, PMID: 22388863

Huemmerich, D. et al. 2006. "Processing and Modification of Films Made from Recombinant Spider Silk Proteins.” Applied Physics A 82: 219-222. DOI: https://doi.org/10.1007/s00339-005-3428-5

Hugo, V. 1837. "Les Voix intérieurs," 4. “A l'Arc de Triomphe," vol. 2. 1837. Pp. 819-831 in Victor Hugo. Euvres completes, Poésie 1. 1985. Edited by C. Gély. Paris: Laffont.

Humenik, M. et al. 2011. "Recombinant Spider Silks—Biopolymers with Potential for Future Applications." Polymers 3: 640-661. DOI: https:// doi.org/10.3390/polym3010640

Hünemörder, C. 2001. “Spinnentiere.” Der Neue Pauly 11: 827-828. 
Jastrzebska, K. et al. 2018. "Delivery of Chemotherapeutics Using Spheres Made of Bioengineered Spider Silks Derived from Masp1 and Masp2 Proteins." Nanomedicine 13(4): 439-454. DOI: https://doi.org/10 .2217/nnm-2017-0276, PMID: 29338625, PMCID: PMC5810845

Johnson, P. J. 2008. Ovid Before Exile. Art and Punishment in the Metamorphoses. Madison: The University of Wisconsin Press.

Johnston, S. I. 2009. “A New Web for Arachne.” Pp. 1-22 in Antike Mythen: Medien, Transformationen und Konstruktionen, edited by U. Dill, and C. Walde. Berlin: de Gruyter. DOI: https://doi.org/10.1515/9783110217247.0.1

Jones, W. H. S. 1963. "Popular Medicine in Ancient Italy." Pp. 569-575 in Pliny, Natural History, Vol. 8, Books 28-32. Edited by W. H. S. Jones. Cambridge, MA/London: Harvard University Press.

Knippers, J. et al. 2016. Biomimetic Research for Architecture and Building Construction: Biological Design and Integrative Structures. Cham: Springer. DOI: https://doi.org/10.1007/978-3-319-46374-2

Koeppel, A., and Holland, C. 2017. "Progress and Trends in Artificial Silk Spinning: A Systematic Review." ACS Biomaterials Science E Engineering 3: 226-237. DOI: https://doi.org/10.1021/acsbiomaterials.6b00669, PMID: 33465923

Krink, T., and Vollrath, F. 1997. "Analysing Spider Web-building Behaviour with Rule-based Simulations and Genetic Algorithms." Journal of Theoretical Biology 185: 321-331. DOI: https://doi.org/10.1006/jtbi .1996 .0306

Kulessa, H. 1991. Die Spinne: Schaurige und schöne Geschichten. Frankfurt am Main-Leipzig: Insel-Verl.

Laks, A., and G. W. Most. 2016. Early Greek Philosophy vol. 7: Later Ionians an Athenian Thinkers, Part 2, ed. and trans. Cambridge, MA: Harvard University Press.

Levi, P. 1985. "Paura dei ragni." Pp. 136-140 in L'Altrui mestiere. Edited by P. Levi. Torino: Einaudi.

Main, B. 1957. "Biology of Aganippine Trapdoor Spiders (Mygalomorphae: Ctenizidae)." Australian Journal of Zoology 5: 402-473. DOI: https://doi .org/10.1071/ZO9570402

Mammola, S. et al. 2016. "Ecological Preference of the Diving Bell Spider Argyroneta aquatica In a Resurgence of the Po plain (Northern Italy) (Araneae: Cybaeidae)." Fragmenta Entomologica 48: 9-16. DOI: https:// doi.org/10.4081/fe.2016.158

Masters, W. M., and Markl, H. 1981. "Vibration Signal Transmission in Spider Orb Webs.” Science 80: 363-365. DOI: https://doi.org/10.1126 /science.213.4505.363, PMID: 17819912

May, M. T. 1968. Galen. On the Usefulness of the Parts of the Body, 2 vols. Ithaca, NY: Cornell University Press. 
Meyer, A. et al. 2014. "Compliant Threads Maximize Spider Silk Connection Strength and Toughness." Journal of the Royal Society Interface 11: 20140561. DOI: https://doi.org/10.1098/rsif.2014.0561, PMID: 25008083, PMCID: PMC 4233707

Miller, F. J. 1977. Ovid. Vol. 3.1. Metamorphoses, Books 1-8, 3rd edn rev. G. P. Goold. Cambridge, MA: Harvard University Press.

Miniaci, M. et al. 2016. "Spider Web-Inspired Acoustic Metamaterials." Applied Physics Letters 109: 071905. DOI: https://doi.org/10.1063/1.4961307

Morgan, E. 2016. Gossamer Days. London: Strange Attractor Press.

Morley, E. L., and Robert, D. 2018. "Electric Fields Elicit Ballooning in Spiders." Current Biology 28: 2324-2330. DOI: https://doi.org/10.1016/j.cub 2018.05.057, PMID: 29983315, PMCID: PMC6065530

Mortimer, B. et al. 2014. "The Speed of Sound in Silk: Linking Material Performance to Biological Function." Advanced Materials 26: 5179-5183. DOI: https://doi.org/10.1002/adma.201401027, PMID: 24902950, PMCID: PMC4140601

Mortimer, B. et al. 2016. "Tuning the Instrument: Sonic Properties in the Spider's Web." Journal of the Royal Society Interface 13: 20160341. DOI: https://doi.org /10.1098/rsif.2016.0341, PMID: 27605164, PMCID: PMC5046944

Most, G. W. 2006. Hesiod, vol. 1. Theogony, Work and Days, Testimonia. Edited and Translated. Cambridge, MA/London: Harvard University Press.

Murray, A. T. 1995. Homer Odyssey, vol. 1-2. London: Heinemann.

Neumann, D., and Woermann, D. 2013. "Stability of the Volume of Air Trapped on the Abdomen of the Water Spider Argyroneta aquatica." Springerplus 2: 694. DOI: https://doi.org/10.1186/2193-1801-2-694, PMID: 24422183, PMCID: PMC3884080

Nyffeler, M., and R. S. Vetter. 2018. "Black Widow Spiders, Latrodectus spp. (Araneae: Theridiidae), and Other Spiders Feeding on Mammals." Journal of Arachnology 46: 541-548. DOI: https://doi.org/10.1636/JoA -S-18-026.1

Pan, L. et al. 2020. "A Supertough Electro-Tendon Based on Spider Silk Composites." Nature Communications 11: 1332. DOI: https://doi.org/10.1038 /s41467-020-14988-5, PMID: 32165612, PMCID: PMC7067870

Pugno, N. M. et al. 2013. "Synergetic Material and Structure Optimization Yields Robust Spider Web Anchorages." Small 9: 2747-2756. DOI: https://doi.org/10.1002/smll.201201343, PMID: 23585296

Pugno, N. M. 2018. "Spider Weight Dragging and Lifting Mechanics." Meccanica 53: 1105-1114. DOI: https://doi.org/10.1007/s11012-017-0787-x Pugno, N. M. 2019. "The Commemoration of Leonardo da Vinci." Meccanica 54: 2317-2324. DOI: https://doi.org/10.1007/s11012-019-01099-9

Rackham, H. 1940. Pliny, Natural History 3, Books 8-11. Cambridge, MA/London: Harvard University Press. 
Reed, C. F. et al. 1970. "Experience and the Orb Web." Developmental Psychobiology 3: 251-265. DOI: https://doi.org/10.1002/dev.420030406, PMID: 5527424

Reinhardt, U. 2014. Arachne und die Liebschaften der Götter: eine Mythennovelle aus Ovids Metamorphoses mit ibrer literarischen und bildlichen Rezeption bis zur Gegenwart. Freiburg i. Br.-Berlin: Rombach.

Rieken, B. 1995. "Die Spinne als Symbol in Volksdichtung und Literatur." Fabula 36: 187-204. DOI: https://doi.org/10.1515/fabl.1995.36.3 $-4.187$

Rising, A., and J. Johansson. 2015. "Toward Spinning Artificial Spider Silk." Nature Chemical Biology 11: 309-315. DOI: https://doi.org/10.1038 /nchembio.1789, PMID: 25885958

Salehi, S. et al. 2020. "Spider Silk for Tissue Engineering Applications." Molecules 25: 737. DOI: https://doi.org/10.3390/molecules25030737, PMID: 32046280, PMCID: PMC7037138

Schacht, K. et al. 2015. "Biofabrication of Cell-Loaded 3D Spider Silk Constructs." Angewandte Chemie International Edition 54: 2816-2820. DOI: https://doi.org/10.1002/anie.201409846, PMID: 25640578

Scharff, N. et al. 2019. "Phylogeny of the Orb-Weaving Spider Family Araneidae (Araneae: Araneoidea)." Cladistics 36: 1-21. DOI: https:// doi.org/10.1111/cla.12382

Schonfield, A. F. 1959. Aelian. On the Characteristics of Animals 2, Books 6-11. London: Heinemann.

Scott, C. E. et al. 2018. "A Review of the Mechanisms and Functional Roles of Male Silk Use in Spider Courtship and Mating." Journal of Arachnology 46: 173-206. DOI: https://doi.org/10.1636/JoA-S-17-093.1

Seymour, R. S., and Hetz, S. K. 2011. "The Diving Bell and the Spider: The Physical Gill of Argyroneta aquatica." Journal of Experimental Biology 214: 2175-2181. DOI: https://doi.org/10.1242/jeb.056093, PMID: 21653811

St-Jacques, J., and P. Renaud. 2006. "Effectiveness of Virtual Reality Exposure in the Treatment of Arachnophobia Using 3D Games." Technology and Health Care 14: 19-27. DOI: https://doi.org/10.3233/THC-2006-14103, PMID: 16556961

Tahir, H. M. et al. 2017. "Spider Silk: An Excellent Biomaterial for Medical Science and Industry." Punjab University Journal of Zoology 32: 143-154.

Vepari, C., and D. L. Kaplan. 2007. "Silk As a Biomaterial." Progress in Polymer Science 32: 991-1007. DOI: https://doi.org/10.1016/j.progpolymsci 2007.05.013, PMID: 19543442, PMCID: PMC2699289

Vincent, J. F. V. et al. 2006. "Biomimetics: Its Practice and Theory." Journal of the Royal Society Interface 3: 471-482. DOI: https://doi.org/10.1098 /rsif.2006.0127, PMID: 16849244, PMCID: PMC1664643 
Vollrath, F., and Porter, D. 2006. "Spider Silk As a Model Biomaterial." Applied Physics A 82: 205-212. DOI: https://doi.org/10.1007/s00339 $-005-3437-4$

Witt, P. N. et al. 1972. "Ontogeny of Web-building Behavior in Two Orbweaving Spiders.” American Zoologist 12: 445-454. DOI: https://doi.org /10.1093/icb/12.3.445

Xing, C. et al. 2013. "Analysis of the Electrothermal Technique for Thermal Property Characterization of Thin Fibers." Measurement Science and Technology 24: 105603. DOI: https://doi.org/10.1088/0957-0233/24/10/105603

Yang, Y. et al. 2020. "Spider (Linothele megatheloides) and Silkworm (Bombyx mori) Silks: Comparative Physical and Biological Evaluation." Materials Science and Engineering C 107: 110197. DOI: https://doi.org/10 .1016/j.msec.2019.110197, PMID: 31761195

Zhang, S. et al. 2019. "Nitrogen Inaccessibility Protects Spider Silk from Bacterial Growth." Journal of Experimental Biology 222, jeb214981. DOI: https://doi.org/10.1242/jeb.214981 